\title{
Desáté výročí encykliky Deus caritas est
}

Editorial

Katedra etiky, psychologie a charitativní práce Teologické fakulty Jihočeské univerzity v Českých Budějovicích v minulém roce pozvala kolegy z dalších kateder v ČR pro obory teorie charity (něm. Caritaswissenschaft) nebo diakonika (něm. Diakonik) na symposium věnované desátému výročí vyhlášení encykliky Deus caritas est. Ślo zřejmě o vůbec první symposium, na kterém se cíleně sešli zástupci těchto pracovišt', která se různým způsobem a na základě různých teologických tradic snaží v českých podmínkách propojit výuku a badatelskou činnost z oblasti praktické teologie (teorie charity, diakonika) se sociální prací. Blížící se výročí vyhlášení encykliky se pro takové setkání jevilo jako velmi příhodné.

Papež Benedikt XVI. encykliku podepsal 25. prosince 2005, slavnostně vyhlášena pak byla o měsíc později 25. ledna 2006. Šlo o jeho nástupní encykliku, která - jak se lze podrobněji dočíst v následujících studiích vzbudila značnou pozornost jak uvnitř, tak vně církve. Encyklika v teologii otevřela do té doby spíše okrajové téma, kterému se na univerzitách věnovalo jen několik málo pracovište. Zdá se proto, že encyklika Deus caritas est určitým způsobem předznamenala pontifikát současného římského biskupa Františka.

Symposium k desátému výročí vyhlášení encykliky se konalo 16. října 2015 v budově Teologické fakulty v Českých Budějovicích. Nyní přinášíme jeden článek a tři odborné studie, které vzešly z referátů na symposiu.

Na základě přednášky hlavního přednášejícího prof. Klause Baumanna z univerzity ve Freiburgu im Breisgau v Německu vznikl článek s názvem „Koncentrace na podstatu křestanské víry a její konsekvence“. Je zde uveden nikoliv jako odborná studie, ale jako uvedení do tématu encykliky Deus caritas est. Klaus Baumann je profesorem na vůbec nejstarší Katedře teorie charity v Evropě. Ve svém článku se postupně věnuje jednak magisteriálnímu kontextu encykliky, jednak jejímu teologickému, antropologickému, eklesiologickému a sociálně-etickému aspektu. Tento svůj komentář zakončuje upozorněním, že zůstala poněkud přehlédnuta intence Benedikta XVI., kterou chtěl svou nástup- 
ní encyklikou vyjádřit, totiž aby se církev přestala zabývat sama sebou a věnovala více pozornosti lidem v nouzi.

Antropologický aspekt pomoci, který se v českém prostředí jeví jako velmi důležitý, pak podrobněji rozvijí studie dr. Jana Hojdy z Katedry kulturních a náboženských studií Pedagogické fakulty Univerzity Hradec Králové, s názvem „Diakonia jako účast člověka na věčném sdílení trojiční lásky: teologicko-antropologická východiska diakonie na pozadí encykliky Deus caritas est". Studie poukazuje na spojitost diakonie s ontologickou strukturou každého člověka a zdůrazňuje, že se proto žádný člověk nemůže službě lásky vyhnout, pokud chce naplnit svou vlastní existenci.

Studie „Farní charity: dozvuky encykliky Deus caritas est a pravděpodobný stav moravských farností“ dr. Jakuba Doležela z Katedry křestanské sociální práce Cyrilometodějské teologické fakulty Univerzity Palackého v Olomouci se věnuje otázce praktické realizace křestanské charity. Vychází proto nejen z encykliky Deus caritas est, ale také z dokumentu, který na ni navázal a kterým Benedikt XVI. svůj pontifikát naopak ukončil, totiž z motu proprio Intima ecclesiae natura. Autor zdưrazňuje, že vedle teologických a právních aspektů realizace charitativního poslání církve ve farnostech je také důležitý manažerský aspekt - zejména ve vztahu organizované profesionální charity a farností.

Studie doc. Michala Opatrného z Katedry etiky, psychologie a charitativní práce Teologické fakulty Jihočeské univerzity v Českých Budějovicích navazuje na dosavadní diskusi o interpretaci 31. článku encykliky, který definuje podstatné znaky křestanské charity. Jak napovídá její název „Podobenství o milosrdném Samaritánovi a proprium křest’anské charitativní práce v kontextu $\mathrm{tzv}$. teorie charity“, studie reflektuje proprium křestanské charity, za které lze na základě encykliky označit orientaci na pomoc lidem, kterým se jinak pomoci nedostává.

Následující článek a studie tak umožňují jednak hlubší vhled do několika klíčových témat encykliky Deus caritas est, jednak i zpřístupňují některé důležité prvky zahraničního teologického diskurzu o obsahu encykliky a jejích dopadech do teologie i pastorační a charitativní praxe.

Michal Opatrný 